\title{
Relationship Between Climate and Diarrhoea
}

\author{
Hasnawati Amqam ${ }^{1}$, Anwar Daud $^{2}$, Serty Ada $^{3}$, Makmur Selomo $^{4}$, Anwar Mallongi ${ }^{5}$, \\ Jumriani Ansar ${ }^{6}$, Yahya Thamrin ${ }^{7}$ \\ \{hasnawati.amqam@unhas.ac.id ${ }^{1}$, anwardaud66@gmail.com², serti.ada10@gmail.com³ \\ mselomo30112@gmail.com ${ }^{4}$, anwar_envi@yahoo.com ${ }^{5}$,jumriani.ansar@gmail.com6 \\ yahyathamrin@yahoo.com ${ }^{7}$ \} \\ Environmental Health Department, Faculty of Public Health, Universitas Hasanuddin ${ }^{1-5}$ \\ Epidemiology Department, Faculty of Public Health, Universitas Hasanuddin ${ }^{6}$ \\ Occupational and Safety Health, Faculty of Public Health, Universitas Hasanuddin, ${ }^{7}$
}

\begin{abstract}
Diarrhea is still a public health problem in developing countries. Climate is one of the contributing factors that may affect the occurrence of diarrhea. This study aimed to determine the relationship between climate, consisted of air temperature, rainfall, and air humidity with the incidence of diarrhea in Tana Toraja District in 2011 2015. The research sample is the number of months in five years from 2011-2015 i.e. 60 months. The univariate analysis showed that average air temperature, rainfall, humidity, and number of diarrhea cases fluctuated up and down each month. Correlation and regression test were used for data analysis. This research showed that there is a significant correlation of air temperature with monthly diarrhea case $(\mathrm{p}=0,005)$ and weak relation $(r=0,35 / 35,7 \%)$ and patterned positive, there is significant relation of rainfall with monthly diarrhea case $(\mathrm{p}=0,000)(\mathrm{r}=0.465 / 46,5 \%)$ and patterned positive, while air moisture per month did not correlate significantly $(\mathrm{p}=0,268)$ and very weak relation $(\mathrm{r}=0,145 / 14,5 \%)$ and patterned positively. The conclusion of this research is climate factor in this case air temperature, and rainfall has a relation with a diarrhea incidence rate in Tana Toraja regency year $2011-2015$.
\end{abstract}

Keywords: Temperature, rainfall, humidity, disease.

\section{Introduction}

Climate change is defined as significant changes in climate and climate variability that persist for long periods. Climate change is an environmental issue that can cause negative impacts that are destructive or can cause disaster. Climate change is global, can occur spatially anywhere [1]. The impacts that are thought to arise from climate change are floods, storms, fires and droughts, and the onset of various diseases.

Indonesia, which is an archipelagic country, has a tropical climate that is diverse and vulnerable to the impacts of climate change. One sector that is vulnerable to the effects of climate change is the health sector, so that anticipation of climate change in the health sector in Indonesia and its environment is significant. One of the diseases which is related to climate change is diarrhea. Elements of climate, namely rainfall, temperature, humidity, and wind speed, affect the incidence of diarrhea [2].

Tropical diarrhea may reach the peak of occurrence in the rainy season. Floods and droughts are associated with an increased risk of diarrhea. Heavy rain might cause the entry 
o,f contaminating agents into the clean water supply, resulting in contaminated water of disease-causing agents such as bacteria [3]. On the other hand, the dry season also still give a chance for diarrhoea increase. The lack of clean water during dry season brings the additions in the risk of hygiene-related diseases, include diarrhea [4].

Tana Toraja Regency is one of the most humid tropical regions, with an average temperature range from $15^{\circ} \mathrm{C}-28^{\circ} \mathrm{C}$ with the humidity between $82-86 \%$, an average rainfall of $1,500 \mathrm{~mm} /$ year to more than $3500 \mathrm{~mm} /$ year. Tana Toraja Regency is primarily a tropical climate with two seasons, based on rainfall namely the rainy season in the period October to March and the dry season in the period April to September. The type of climate in Tana Toraja Regency is type C2 wherein the wet month $(200 \mathrm{~mm})$ is for $2-3$ consecutive months and the dry months $(100 \mathrm{~mm})$ is for $2-3$ consecutive months. ${ }^{5}$ This study aimed to observe the effect of rainfall, temperature, humidity to diarrhea case in Tana Toraja Regency during 2011-2015.

\section{Methods}

This research is a time series of ecological study. It was located in Tana Toraja Regency, with 19 sub-districts. The population of the study was the number of months in the period 2011-2015. The data included in this study were secondary data taken from the Tana Toraja District Health Office and climatic data (air temperature, humidity, and rainfall) that obtained from the Center for Climatology and Geophysics Meteorology of the Class IV Meteorological Station Pongtiku Tana Toraja in 2011-2015. The data were analyzed using correlation test.

\section{Result}

\subsection{Air Temperature in Tana Toraja Regency 2011 - 2015}

The results showed that the average annual temperature in Tana Toraja Regency rises every year. The highest average temperature of Tana Toraja Regency was in November 2015 $\left(25.1^{\circ} \mathrm{C}\right)$, and the lowest average air temperature was in July $2011\left(19^{\circ} \mathrm{C}\right)$. The average air temperature during 2011-2015 was $22.7^{\circ} \mathrm{C}$ (SD 1.437) (Graph 1).

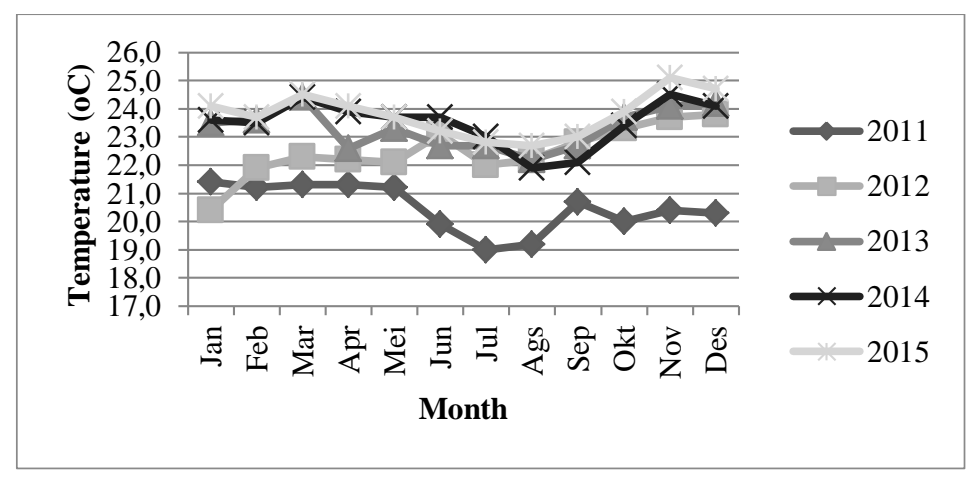

Graph. 1 Air Temperature in Tana Toraja Regency 2011 - 2015 


\subsection{Humidity}

The highest average humidity in Tana Toraja Regency in 2011 was $79.33 \%$, and the lowest average in 2015 was $74.83 \%$. The annual average humidity in Tana Toraja Regency almost decreases every year. The average humidity during 2011-2015 was 76.90\%. The lowest humidity during 2011-2015 was $63 \%$ with the highest longitude at $83 \%$. In the whole year, the humidity falls from July to December (Graph 2).

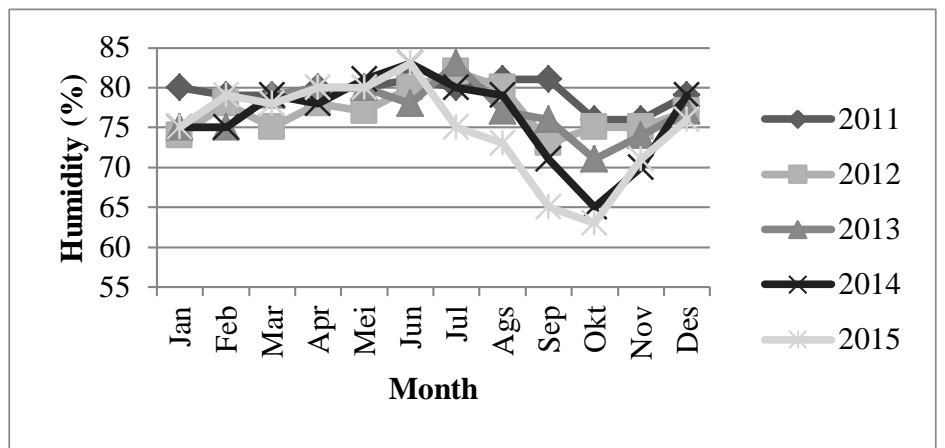

Graph 2. The Average of Humidity Monthly in Tana Toraja, the Year of $2011-2015$

\subsection{Rainfall}

The highest average rainfall in Tana Toraja Regency was in 2012, reached $278 \mathrm{~mm}$ and the lowest of it is in 2014 , down to $187.3 \mathrm{~mm}$. The average annual rainfall in Tana Toraja Regency was fluctuated each year. The average air temperature during 2011-2015 was 239.07 $\mathrm{mm}$ (SD 149.503). The lowest air temperature during 2011-2015 was $0 \mathrm{~mm}$, with the highest air temperature of $599 \mathrm{~mm}$ (Graph 3).

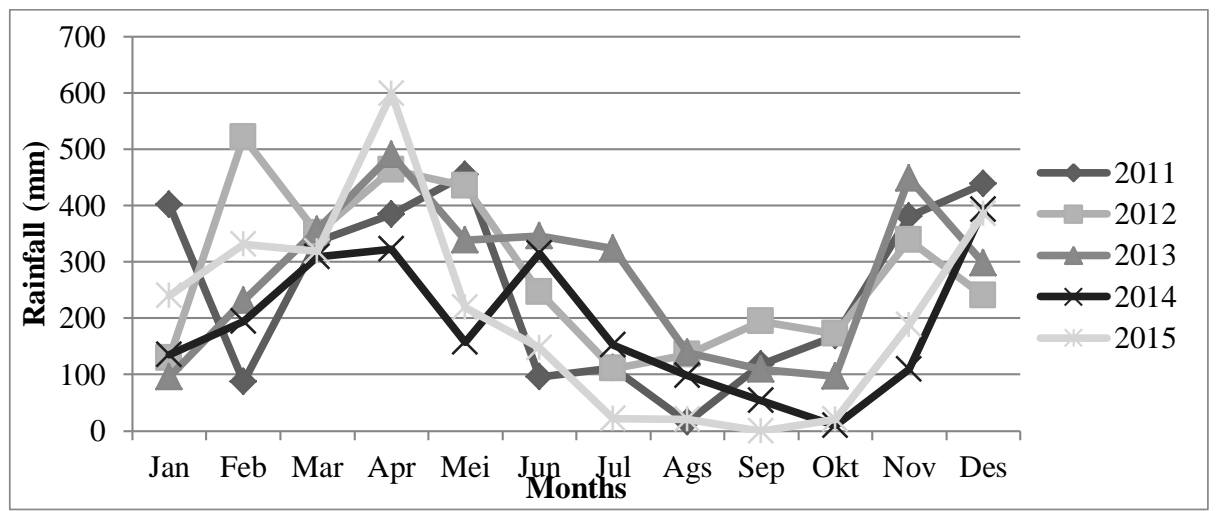

Graph 3. The Average of Rainfall Monthly in Tana Toraja, Year of 2011 - 2015 


\subsection{Diarrhoea}

The highest incidence of Diarrhoea was observed in 2015, which was 6,712 cases, and the lowest was in 2012 with 4,810 cases. Annual cases of diarrhoea were increased from 2012 to 2015. The average case of diarrhoea during 2011-2015 was 488.48 (SD 164.633). The lowest cases of diarrhoea during 2011-2015 were 170 cases, and the highest cases were 996 cases (Graph 4).

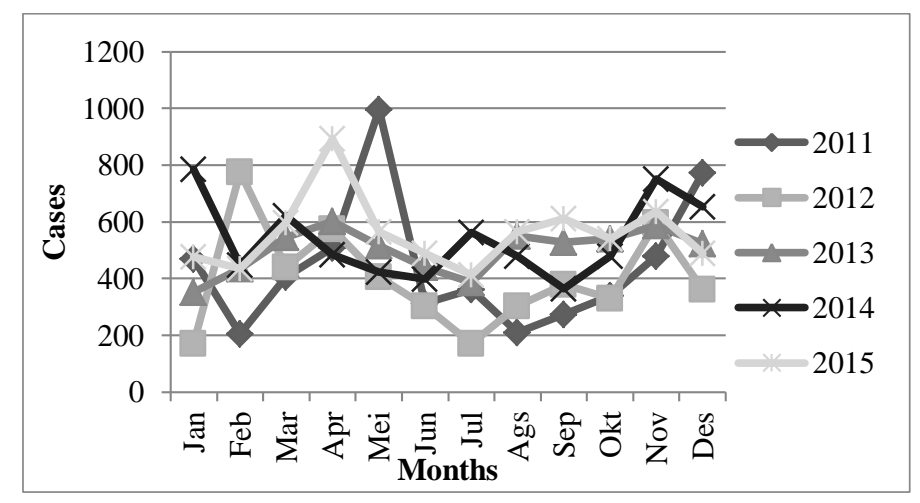

Graph 4. Overview of Monthly Diarrhea Incidence Figures in Tana Toraja Regency in 2011 - 2015

The analysis showed that there was a significant relationship between air temperature and diarrhoea cases $(\mathrm{p}=0.005)$, and the correlation test showed a weak correlation $(\mathrm{r}=0.357)$ between the two variables. The correlation test between humidity and diarrhoea incidence showed that there was no significant relationship between humidity and diarrhoea cases $(\mathrm{p}=$ $0.268, \mathrm{r}=0.145)$. However, it indicated a positive pattern that might be interpreted as the higher humidity, the higher diarrhea cases. The correlation test results between rainfall and diarrhoea incidence showed that there was a significant relationship $(\mathrm{p}=0,000)$ and a moderate correlation $(r=0,465)$ between those variables, with a positive pattern that indicated more significant rainfall, the higher the number of diarrhoea cases (Table 1).

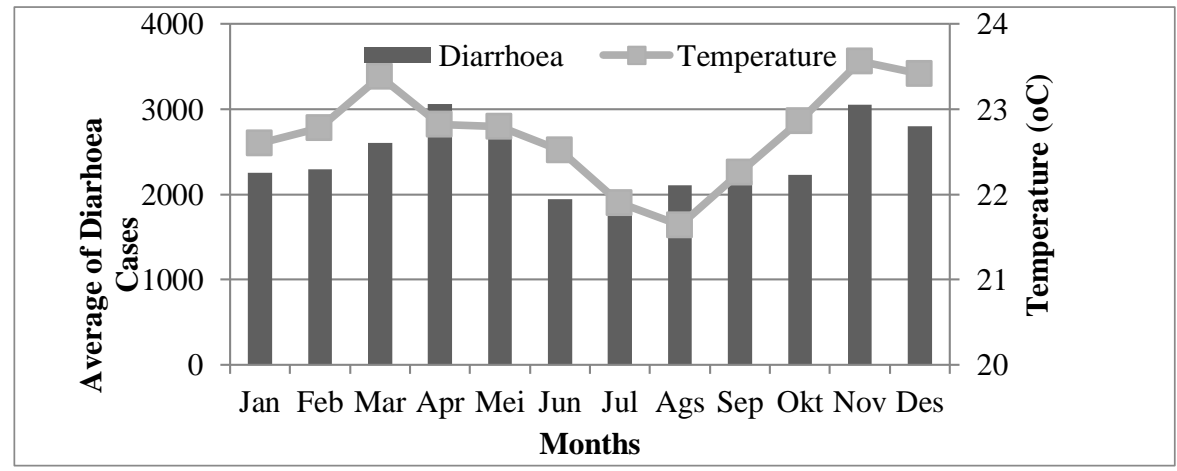

Graph 5. The relationship between Air Temperature and Diarrhoea in Tana Toraja Regency, 2011- 


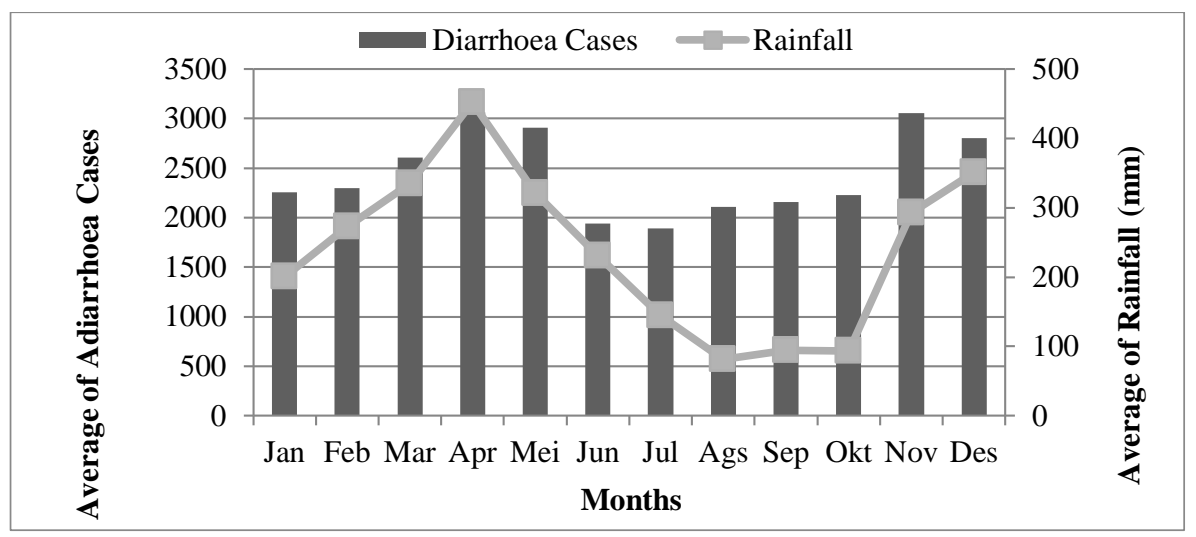

Graph 6. The Relationship between rainfall and Diarrhoea in Tana Toraja Regency, 2011 - 2015
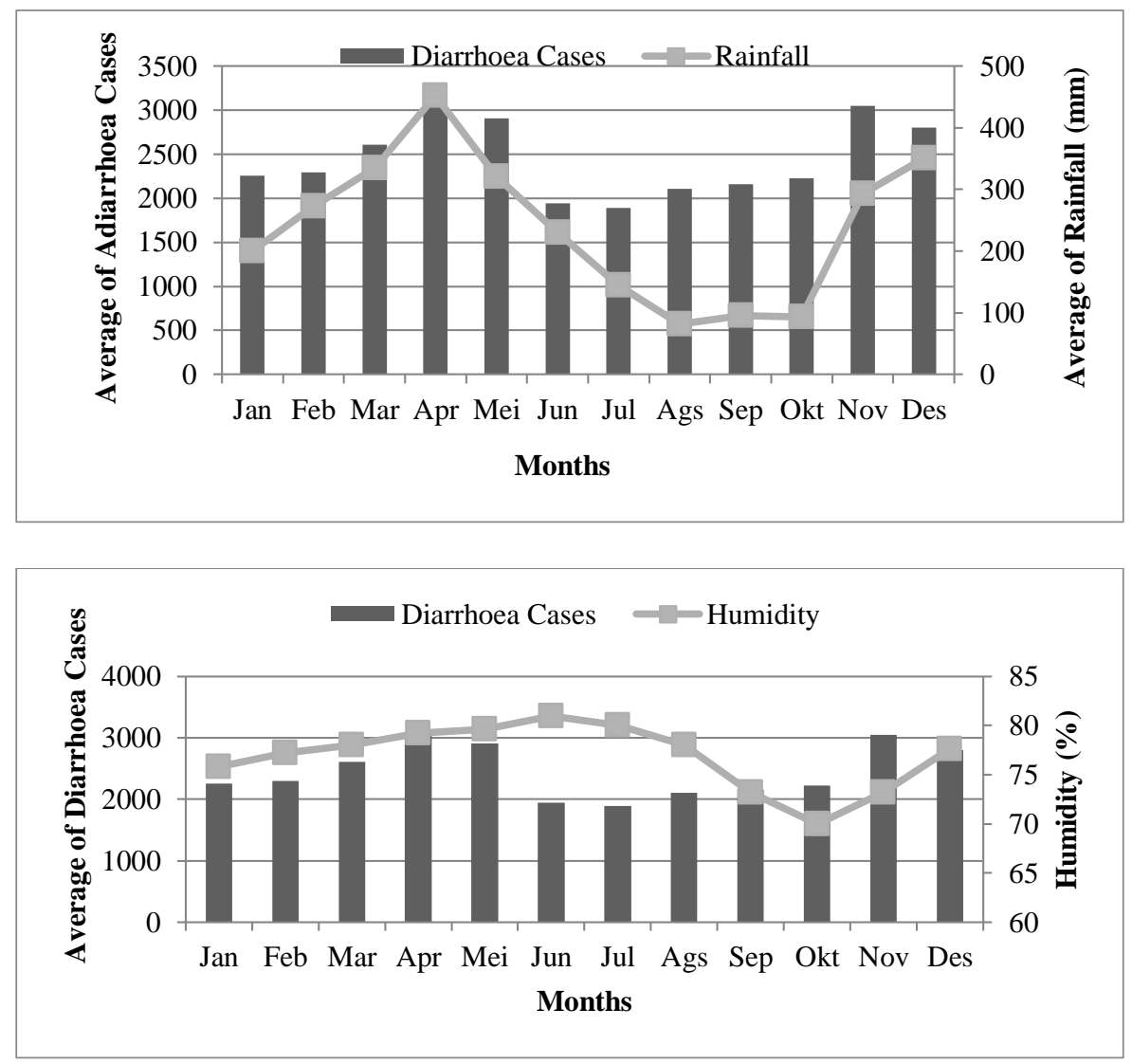

Graph 7. The Relationship Between Humidity and Diarrhoea in Tana Toraja Regency, 2011 2015 
Table 1. Correlation and Regression analysis of Variables, with Diarrhoea at Tana Toraja Regency, $2011-2015$

\begin{tabular}{cccc}
\hline Variables & \multicolumn{1}{c}{ Equation } & p-value \\
\hline Temperature & 0,357 & $\mathrm{Y}=-441,4+40,944 *$ suhu & 0,005 \\
Curah hujan & 0,465 & $\mathrm{Y}=366.004+512 *$ curah hujan & 0,000 \\
Kelembaban & 0,145 & $(\mathrm{Y}=921.4+5.630 *$ kelembaban & 0,268 \\
& &, & \\
\hline
\end{tabular}

\section{Discussion}

Diarrhoea is still a health problem in developing countries such as Indonesia because of its high mortality and mortality [5]. According to Maryani and Mullane climate conditions such as air temperature, rainfall, and humidity can also affect the incidence of diarrhoea. Diarrhoea cases always present throughout the year in Tana Toraja Regency [6].

The diarrhoea data was obtained from the Tana Toraja District Health Office, which came from monthly reports from 21 Community Health Centres and hospitals in Tana Toraja Regency. The data has been recapitulated by the P2 Diarrhea program manager. Based on the data, in 2015, diarrhoea was included in the top ten diseases and was the 7 th position with the total of 10,615 cases [7].

In this study, the correlation analysis showed that there was a significant relationship between air temperature and diarrhoea cases. It was showed a weak and positive pattern, meaning that $1{ }^{\circ} \mathrm{C}$ increase of temperature would increase diarrhoea cases by 40,944 and the value of $\mathrm{R}$ square $(0.128)$ means that $12.8 \%$ variation in air temperature could explain the diarrhoea cases. The results of this study were in line with the results of the research conducted by Ernyasih in Palembang that there was a significant relationship between air temperature and diarrhoea cases $(\mathrm{p}=0.005)$. Prevalence of diarrhoea in Palembang within 2000-2004. The results showed that there was a weak correlation between the increase in temperature and the prevalence of diarrhoea $(r=0.11)$ [8].

Rainfall can affect the spread of various microorganisms that will result in the spread of diarrheal diseases through a mechanism where the rain pollute the water by transferring human and animal waste to groundwater. The microorganisms might include cryptosporidium, giardia, and E. Coli.11 The risk may increase due to the high rainfall that brings flood then contaminate clean water supplies. When rainfall is low, droughts occur and can reduce the supply of clean water, so that increase the risk of hygiene-related diseases such as diarrhea.

The incidence of diarrhoea in Tana Toraja Regency in 2011-2015 tended to increase from January to April along with rainfall, which also increased from January to April. Diarrhoea might be emerged due to lack of clean water. It can be seen as well from this study that the monthly average rainfall during the period of 2011-2015 in Tana Torajaya District was $239,068 \mathrm{~mm}$, with the highest range of monthly 521. It was found that the correlation of rainfall with diarrhoea cases showed a moderate relationship $(r=0.465 / 46.5 \%)$ and a positive pattern, meaning that the higher the rainfall, the higher the case of diarrhoea. Based on the monitoring of the Class IV Meteorology Station in Pongtiku Tana Toraja in 2011 - 2015 
changes in rainfall occurred which only explained $21.6 \%$ of the incidence of diarrhoea cases in Tana Toraja Regency from 2011-2015.

The results are in line with the research of Lidia Oktavia,12 that the significant relationship between rainfall and diarrhoea $(\mathrm{p}=0.031, \mathrm{r}=0.621)$. The relationship showed a strong relationship and positive pattern, meaning that an increase of rainfall of $1 \mathrm{~mm}$ increased diarrhoea cases by 1.142 and $\mathrm{R}$-square value of 0.386 , meaning that $38.6 \%$ variation in rainfall could explain diarrhoea cases. This is also in line with Kurniawan's research, which states that there is a rainfall relationship with diarrhoea cases in South Jakarta City in 2007-2011.1313.

Humidity changes will affect vector populations, which can cause harm to health. According to Mairusnita14, the humidity came from the rainy season, so that the bacteria will live longer and in the conditions of lack of ventilation homes, it will accelerate the disease transmission process.[9-12] The results of this study indicate that humidity has no significant relationship to the incidence of diarrhoea. Besides that, it was also determined by a strong correlation with humidity (> 85\%) and temperature of $29^{\circ} \mathrm{C}$ with cholera. 15 From the analysis, it was found that in January to April, the number of cases of diarrhoea increased with the highest cases occurring in April. The highest average state of humidity recorded from 2011 to 2015 occurred in June with a five-year average of $81 \%$. During the last five years, the average humidity in Tana Toraja Regency began to increase from January to its peak in June.

\section{Conclusion}

The incidence of diarrhoea every year 2011-2015 in Tana Toraja Regency tends to increase. The highest monthly air temperature averages during 2007-2011 occurred in November 2015and the lowest occurred in July 2011. The highest monthly rainfall average during 2011-2015 occurred in April 2015, which was equal to $598.5 \mathrm{~mm}$ and the lowest monthly rainfall average occurred in September 2015, which was $0 \mathrm{~mm}$. The highest average monthly humidity during 2011-2015 occurred in July 2013, June 2014 and June 2015, which was $83 \%$ and the lowest monthly humidity occurred in October 2015, which was 63 . There was a significant but weak relationship of temperature air with the cases of diarrhoea. There is a significant and moderate relationship between rainfall and the cases of diarrhoea. There was no significant relationship between air humidity $(\mathrm{p}=0.268)$ and diarrhoea. It is recommended to the Tana Toraja District Health Office that it is necessary to take preventive measures specifically for managing P2 Diarrhea programs in anticipating diarrhoea cases. For the community to remain vigilant and avoid diarrheal disease attacks by always maintaining Healthy Living Behavior (PHBS).

\section{References}

[1] Lisanuddin., Ismail., Aulia, B 2016 Hubungan pengetahuan perubahan iklim dan sikap masyarakat terhadap kejadian penyakit malaria di wilayah Kecamatan Darul imarah Kabupaten Aceh Besar J. Universitas Syiah Kuala Vol.16.pp. 2 (2016)

[2] McIver, Lachlan.: Health impacts of climate change in Pacific Island Countries: a regional assessment of vulnerabilities and adaptation priorities. Environmental Health Perspectives Vol.11.pp. $124(2016)$

[3] Kementrian Kesehatan RI.: Situasi diare di Indonesia Jakarta Kementerian Kesehatan RI (2011)

[4] Athena, D \& Anwar, M. 2014 Penelitian/pengembangan model/sistem surveilans dampak kesehatan perubahan iklim. Bul. Penelitian Kesehatan Vol .42.pp. 1 (2014) 
[5] Kementerian Kesehatan RI.: Buku pedoman pengendalian penyakit diare (Jakarta Kementerian Kesehatan RI) (2010)

[6] Maryani, L., Muliani R.: Epidemiologi kesehatan pendekatan penelitian (Yogyakarta Graha Ilmu) (2010)

[7] Dinas Kesehatan Kabupaten Tana Toraja.: Profil Kesehatan Tana Toraja Tahun 2015 (Tana Toraja: Dinas Kesehatan Kabupaten Tana Toraja) pp.1-5 (2015)

[8] Nersan Y.: Hubungan Variasi Iklim dengan Prevalensi Diare di Kota.pp.34-50 (2007)

[9] Mairusnita.: Karakteristik Penderita Penyakit Infeksi Saluran Pernapasan Akut (ISPA) pada Balita yang berobat ke Badan Pelayanan Kesehatan Rumah Sakit Uum Daerah ( BPKRSUD) di Kota Langsa Tahun 2006 Skripsi (Medan:Universitas Sumatera Utara).pp.49-59 (2007)

[10] Anwar Mallongi, Darwin Safiu, Hasnawati Amqam, Aminuddin Syam, Muhammad Hatta, Tatik Sutarti, Muhith Abdul, Sandu Siyoto and Apollo. Modelling of $\mathrm{SO}_{2}$ and CO Pollution Due to Industry PLTD Emission Tello in 2 Makassar Indonesia. Journal of Engineering and Applied Sciences,vol.14.pp. 634-640 (2019)

[11] Rajendran K .: Influence of Relative Humidity in Vibrio Cholerae Infection: A time series model. Indian Journal of Medical Research. Vol.133.pp.138-145 (2011)

[12] Amqam, H., Hermawati, E., Hartono, B., Pratama, S., Mallongi, : A. Biomonitoring persistent organic pesticides residues in Indonesian farmers and agricultural products. Indian Journal of Ecology. Vol.45.pp.858-865 (2018) 